\title{
HUBUNGAN MEKANISME KOPING DENGAN PROSES BERKABUNG PADA PASIEN PRE OPERASI KANKER
}

\author{
Deni Kurniawan*, Idawati Manurung*, Rohayati* \\ *Jurusan Keperawatan Poltekkes Tanjungkarang
}

\begin{abstract}
Kanker akan berdampak pada penderita baik secara fisik maupun psikologis. Kondisi tersebut dirasakan sebagai bentuk kekecewaan atau krisis yang dialami oleh penderita. Tekanan-tekanan inilah yang berpeluang menimbukan masalah emosional (psikologis) yang ditunjukkan dengan terjadinya proses berduka pada pasien kanker. Tujuan penelitian ini untuk mengetahui hubungan mekanisme koping dengan proses berkabung pada pasien pre operasi kanker. Desain penelitian menggunakan desain survey dengan pendekatan cross sectional. Pengambilan sampel dilakukan dengan teknik accidental sampling. Jumlah sampel sebanyak 32 responden. Instrumen yang digunakan untuk pengumpulan data adalah lembar kuesioner. Analisis statistik menggunakan uji chi-square. Hasil analisis didapatkan bahwa 14 responden yang memiliki mekanisme koping maladaptif $(43,8 \%)$ dan yang memiliki koping adaptif ada $18(56,2 \%)$. Pada proses berkabung tidak baik $19(59,4 \%)$ dan baik $13(40,6 \%)$. Hasil uji statistik juga mendapatkan nilai $\rho$ value $0,28>\alpha(0,05)$, maka dapat disimpulkan bahwa tidak ada hubungan antara mekanisme koping dengan proses berkabung pada pasien pre operasi kanker. Peneliti menyarankan agar mencari faktor lain yang dapat membantu pasien untuk melewati fase proses berkabung.
\end{abstract}

Kata Kunci: Kanker, Mekanisme Koping, Pre Operasi, Proses Berkabung

\section{LATAR BELAKANG}

Kanker merupakan salah satu penyakit yang paling ditakuti dan dipandang sebagai penyebab utama kematian di seluruh dunia. Penyakit ini masih merupakan ancaman bagi kesejahteraan dan kesehatan manusia pada umumnya. World Health Organization (WHO) (2009). mengungkapkan terjadi peningkatan jumlah penderita kanker setiap tahunnya hingga mencapai 6,25 juta orang dan dua pertiganya berasal dari negara berkembang termasuk Indonesia.

\section{National Cancer Institute} mengungkapkan dari 7,6 juta kematian di dunia yang terjadi 13,0\% kematian tersebut disebabkan oleh penyakit kanker dan 458 ribu adalah kasus kanker payudara. Stanford Medicine (Adrian, 2011). Provinsi Lampung menempati urutan nomor kedelapan dalam prevalensi kanker tertinggi di Indonesia. Kasus penyakit kanker yang ditemukan di Provinsi Lampung pada tahun 2013 sebanyak 5.517 kasus. Penyakit kanker terbesar yaitu kanker payudara 1.148, kanker servik 765 kasus dan kanker prostat 406. (Kemenkes RI, 2014).
Berdasarkan hasil pre survei peneliti pada tanggal 19-20 April 2018 di ruang Mawar dan Kutilang RSUD Dr. Hi. Abdul Moeloek Provinsi Lampung didapatkan data dari Medical Record bahwa jumlah penderita kanker selama bulan September 2017 sampai April 2018 sebanyak 406 pasien dan hasil wawancara dengan empat orang responden pasien baru ditemukan kedua responden menyatakan bahwa mereka mengalami berbagai perubahan dalam menjalani hidupnya sejak dirawat. Mereka menyatakan bahwa saat awal terdiagnosa kanker pada dirinya mereka merasa tidak percaya, timbul perasaan malu dan menarik diri dengan kondisinya yang sekarang dan bingung apa yang akan terjadi kepada dirinya, sedangkan dua responden nya lagi menyatakan bahwa penyakit yang dirasakan sekarang merupakan pola hidup dimasa muda yang tidak sehat dan siap menerima kenyataan.

Penelitian Lanreville dan koleganya, 2009 dalam Wita 2015, menunjukkan bahwa masalah yang umum terjadi pada seseorang yang mengalami kanker adalah kehilangan yang menimbulkan respon berduka. Kehilangan yang dimaksud merupakan kehilangan bagian tubuh akibat penyakit kanker yang menimbulkan 
kecacatan atau pembatasan, baik pembatasan sehari-hari maupun peran sosial yang memunculkan ansietas dan kesedihan. Pemicu munculnya rasa berduka pada penderita kanker karena ketidakmampuannya beradaptasi untuk menerima kecacatan akibat terapi dan menimbulkan perasaan sedih dan tak berguna (Townend, et al., 2010, dalam Wita 2015). Kubler-Ross (1969) dalam Potter \& Perry (2005) menyatakan respon berduka berorientasi pada perilaku dan menyangkut kedalam 5 fase yaitu menyangkal (denial), marah (anger), tawar-menawar (bargaining), depresi (depression), dan penerimaan (acceptance). Respon berduka yang muncul pada penderita kanker merupakan akibat dari kehilangan yang dirasakan oleh seseorang yang akan atau sebelum mengalami terapi. Seperti diketahui, berduka merupakan respon normal pada semua kejadian kehilangan. Umumnya respon emosi yang diekspresikan terhadap kehilangan dimanifestasikan dengan perasaan sedih, gelisah, cemas, sesak nafas, susah tidur, dan lain-lain (NANDA, 2011 dalam Wita 2015).

Koping dipandang sebagai suatu faktor penyeimbang yang dapat membantu invidu beradaptasi dengan kondisi yang menekan dan dapat menimbulkan berduka Mekanisme koping adalah mekanisme yang digunakan individu untuk menghadapi perubahan yang diterima. Kemampuan koping individu tergantung dari temperamen, presepsi, dan kognisi serta latar belakang budaya/norma tempatnya dibesarkan (Nursalam, 2011 dalam Dyanna dkk, 2015).

\section{METODE}

Metode penelitian ini adalah survey dengan pendekatan cross sectional. Populasi dari penelitian ini adalah pasien pre operasi kanker di sebuah rumah sakit di Kota Bandar Lampung. Jumlah sampel pada penelitian ini adalah 32 responden. Instrumen pengumpulan data dalam penelitian ini menggunakan lembar kuisioner. Berupa kuesioner mekanisme koping dan proses berkabung. Uji analisis menggunakan uji chi-square.

\section{HASIL}

Penelitian menggunakan 32 responden dengan karakteristik sebagian besar berusia dewasa akhir dengan rentang umur 36-45 tahun (56,3), berpendidikan SMA $(50,0 \%)$ dan bekerja sebagai wiraswasta $(59,4$.

Tabel 1: Distribusi Frekuensi Mekanisme Koping

\begin{tabular}{lcc}
\hline \multicolumn{1}{c}{ Mekanisme Koping } & f & $\%$ \\
\hline Adaptif & 18 & 56,2 \\
\hline Maladaptif & 14 & 43,8 \\
\hline Jumlah & 32 & 100 \\
\hline
\end{tabular}

Dari hasil penelitian pada tabel di atas didapatkan sebagian besar mekanisme koping adalah mekanisme koping adaptif sebanyak 18 orang $(56,2 \%)$.

Tabel 2: Distribusi Frekuensi Proses Berkabung

\begin{tabular}{lcc}
\hline \multicolumn{1}{c}{ Proses Berkabung } & f & $\%$ \\
\hline Baik & 13 & 40,6 \\
\hline Tidak Baik & 19 & 59,4 \\
\hline Jumlah & 32 & 100 \\
\hline \multicolumn{1}{c}{ Proses Berkabung } & $\mathrm{f}$ & $\%$ \\
\hline Denial & 6 & 18,8 \\
\hline Anger & 13 & 40,6 \\
\hline Bargaining & 3 & 9,4 \\
\hline Depression & 10 & 31,2 \\
\hline Jumlah & 32 & 100 \\
\hline
\end{tabular}

Pada tabel di atas didapatkan sebagian besar proses berkabung berada pada proses berkabung tidak baik dengan jumlah responden $19(59,4 \%)$ dan fase berkabung yang paling banyak adalah difase Anger sebanyak 13 orang (40,6\%). 
Tabel 3: Distribusi Analisis Uji ChiSquare Mekanisme Koping dengan Proses Berkabung

\begin{tabular}{|c|c|c|c|c|c|c|c|}
\hline \multirow{3}{*}{$\begin{array}{c}\text { Mekanisme } \\
\text { koping }\end{array}$} & \multicolumn{4}{|c|}{ Proses berkabung } & \multirow{2}{*}{\multicolumn{2}{|c|}{ Total }} & \multirow{3}{*}{$\begin{array}{c}\rho \\
\text { value }\end{array}$} \\
\hline & \multicolumn{2}{|c|}{ Tdk baik } & \multicolumn{2}{|c|}{ Baik } & & & \\
\hline & $\mathrm{f}$ & $\%$ & $\mathrm{f}$ & $\%$ & $\mathrm{f}$ & $\%$ & \\
\hline & 9 & 50,0 & 9 & 50,0 & 18 & 100 & \\
\hline & 4 & 6 & 10 & 71,4 & 14 & 100 & \\
\hline & 13 & 40,6 & 19 & 59,4 & 32 & 100 & \\
\hline
\end{tabular}

Berdasarkan tabel di atas dapat disimpulkan bahwa dari 18 responden yang memiliki mekanisme koping maladaptif ada $9(50,0 \%)$ dengan proses berkabung tidak baik. Kemudian dari 14 responden yang memiliki koping adaptif ada $4(28,6 \%)$ yang mengalami proses berkabung tidak baik. Pada uji statistik dengan Chi-Square diperoleh nilai $\rho$ value $0,28>a(0,05)$, maka dapat disimpulkan bahwa Ho diterima yang artinya tidak ada hubungan mekanisme koping dengan proses berkabung.

\section{PEMBAHASAN}

\section{Mekanisme Koping}

Mekanisme koping adalah mekanisme yang digunakan individu untuk menghadapi perubahan yang diterima terhadap situasi yang mengancam dirinya baik fisik maupun psikologi. Menurut stuart dan laraia mekanisme koping dipengaruhi oleh faktor internal dan eksternal. Faktor-faktor eksternal mekanisme koping adalah dukungan sosial, pendidikan, pekerjaan, dan sumber material sedangkan untuk faktor internal yaitu kesehatan dan usia. Pada penelitian ini usia terbanyak yaitu dewasa akhir dengan rentang usia 36-45 tahun.

Menurut kubler-ross pada usia muda kemampuan menggunkan koping lebih baik dibandingkan dengan orang yang sudah lanjut karna pada usia itu mereka mampu mengisi fikiran positif sehingga mempunyai harapan yang lebih baik. Menurut peneliti pada usia ini individu mampu menyelesaikan masalah yang dihadapi dengan cara menggunakan koping yang baik sehingga individu mampu menyelesaikan fase-fase berkabung. Menurut Suseno pendidikan dan pekerjaan mempengaruhi mekanisme koping. Hal ini juga diperkuat dengan teori Notoatmodjo (2010), yang menyatakan bahwa semakin tinggi pendidikan, maka ia akan mudah menerima hal yang baru dan akan mudah menyesuaikan hal tersebut.

Pada penelitian ini pendidikan responden terbanyak adalah SMA, jadi menurut peneliti pendidikan yang tinggi mampu menggunakan koping yang adaptif sehingga mampu menyelesaikan masalah dan mempunyai harapan untuk sembuh dari penyakit yang dialami. Pada penelitian ini perbandingan mekanisme koping adaptif dengan maladaptif sangat sedikit dikarnakan menurut peneliti ada 18 responden memiliki koping adaptif siap untuk akan dioperasi namun untuk 14 responden tidak siap dilakuakan operasi dan penyakit yang dialami sehingga menyababkan koping menjadi maladaptif.

Hal ini sejalan dengan pendapat (Candra 2012), mengenai mekanisme koping dengan tingkat kecemasan pada pasien kanker didapatkan hasil bahwa mayoritas responden memiliki mekanisme koping yang berorientasi pada masalah, reaksi ini merupakan koping yang digunakan dalam mengatasi masalah dengan berorientasi pada proses penyelesaian masalah meliputi, kognitif, afektif atau perasaan, dan psikomotor. Reaksi ini dapat dilakukan seperti berbicara dengan orang lain mengenai masalah yang dihadapi, mencari informasi sebanyak mungkin mengenai penyakitnya dan melakukan aktifitas yang dapat mengurangi stres.

Menurut peneliti koping yang afektif menghasilkan adaptasi yang menetap yang merupakan kebiasaan baru dan perbaikan dari situasi yang lama, sedangkan koping yang tidak efektif berakhir dengan maladaptif yaitu perilaku yang menyimpang dari keinginan normatif dan dapat merugikan diri sendiri maupun orang lain dan lingkungan.

Pada variabel mekanisme koping sejalan dengan (Lenny Dyana, dkk, 2015) dengan hasil uji Chi-Square dengan judul 
"Hubungan Dukungan Keluarga Terhadap Mekanisme Koping Pada Pasien Post Operasi Mastektomi Di Ruang Anyelir Dan Cenderawasih I RSUD Arifin Achmad PekanBaru". Dari hasil penelitiannya didapatkan dari 30 responden terdapat 17 responden (85\%) memiliki mekanisme koping yang adaptif. Hasil uji Chi-Square didapatkan $p$ value sebesar 0,030 , berarti $p$ value < $a(0,05 \%)$. Hal ini berarti Ho ditolak dan dapat disimpulkan bahwa ada hubungan dukungan keluarga terhadap mekanisme koping pada pasien post operasi mastektomi.

\section{Proses Berkabung}

Proses berkabung dipengaruhi oleh banyak faktor salah satunya dukungan keluarga, jika dukungan keluarga tidak baik maka akan mempengaruhi mekanisme koping yang digunakan sehingga proses berkabung menjadi tidak akan sukses atau berhenti disalah satu fase berkabung Menurut peneliti proses berkabung tidak baik baerada di fase denial, anger, bargaining, and depression. Kemudian untuk setiap fasenya ada fase denial sebanyak 6 responden $(18,8 \%)$, anger sebanyak 13 responden $(40,6 \%)$ dan fase bargaining sebanyak 3 responden $(9,4 \%)$ dan depression sebanyak 10 orang $(31,2 \%)$.

Menurut Potter \& Perry (2005), berduka atau berkabung adalah respon normal terhadap setiap kehilangan. Perilaku dan perasaan yang berkaitan dengan respon berduka terjadi pada individu yang menderita kehilangan seperti perubahan fisik atau kematian teman dekat. Proses ini juga terjadi ketika individu menghadapi kematian mereka sendiri. Proses berduka menurut teori KubblerRoss tahun 1969 ada 5, yaitu denial, anger, bargaining, depression, dan acceptance. Hal ini dipengaruhi oleh beberapa faktor yaitu, usia, pendidikan, pekerjaan, status sosio-ekonomi, kehilangan yang dialami, support system (dukungan keluarga).

Kehilangan pekerjaan atau kesejahteraan ekonomi, perceraian, atau kerusakan fisik menyebabkan dukacita yang mendalam dan mengancam keberhasilan. Pada usia baya mulai menyadari bahwa kemudaan dan kebugaran fisik tidak dapat dijadikan jaminan. Usia dewasa mulai menelaah kembali tentang hidup untuk mempertimbangkan pilihan yang tersedia untuk mencapai kesempurnaan. Lansia sering mengalami banyak kepuasan hidup jika dibandingkan dengan yang usia muda (Potter \& Perry, 2005). Pekerjaan dari responden yang respon sebagian besar swasta dan ibu rumah tangga. Seseorang yang dihadapkan dengan kehilangan yang berat dan kesulitan ekonomi mungkin tidak mampu menghadapi keduanya.

Menurut Suseno (2005) kekurangan keuangan atau tidak memiliki pekerjaan yang dianggap layak memperbesar stress pada orang yang berduka maka diperlukannya dukungan eksternal yaitu dukungan keluarga yang akan membuat koping seseorang menjadi baik. Responden yang tidak merasakan adanya dukungan keluarga dengan baik tentu akan berdampak pada kopingnya untuk menyelesaikan masalah yang dihadapi sehingga respon berduka yang dialami belum sampai pada fase menerima. Menurut Rando (dalam Suseno, 2005), kehilangan support biasanya mengacu pada kesulitan koping seseorang untuk mengatasi masalah berduka dengan sukses atau baik.

Respon berduka pada fase denial sebanyak $6 \quad(18,8 \%)$ dan sebanyak bargaining 3 (9,4\%). Menurut KublerRoss, (1969) dalam Potter and Perry, (2005) pada fase denial dan bargaining akan tampak koping pada individu ingin menghindari penerimaan realitas situasi dengan tidak mampu membuat keputusan, tidak menerima kenyataan tentang kondisinya sekarang dan mencari bukti tentang kehilangan serta membuat penawaran terhadap Tuhan Yang Maha Esa. Menurut peneliti jika dampak dari fase tersebut tidak dapat diminimalisir akan menyebabkan koping individu tidak berjalan dengan baik sehingga untuk melanjutkan ke fase berikutnya akan sulit, 
maka dari itu perlu dukungan eksternal terutama keluarga terdekat

Respon berduka pada fase anger sebanyak $13(40,6 \%)$ dan depression sebanyak 10 (31,2\%). Kubler-Ross (1969 dalam Videbeck, 2008) mengatakan fase marah adalah fase dimana individu menolak kehilangan dengan mengungkapkan kemarahan yang diproyeksikan atau diekspresikan kepada Tuhan, keluarga, teman, pemberi perawatan kesehatan, atau diri sendiri. Stuart dan Sundeen (1987 dalam Keliat, 1996) mengatakan marah akibat kehilangan adalah perasaan jengkel yang timbul sebagai respon terhadap kecemasan yang dirasakan sebagai ancaman. Banyak situasi kehidupan yang menimbulkan marah, misalnya fungsi tubuh yang terganggu sehingga harus masuk rumah sakit, kontrol diri yang diambil-alih orang lain akibat menderita sakit, peran yang tidak dapat dilakukan karena dirawat di rumah sakit, pelayanan perawat yang terlambat, dan banyak hal lain yang menimbulkan kejengkelan individu.

Hal ini tidak sejalan dengan penelitian Triwibowo (2012) yang mengatakan bahwa 9 orang dari pasien kanker yang berduka karena penyakit kanker yang dialaminya mereka tidak mengalami fase anger dan fase depression, melainkan hanya mengalami fase denial dan bargaining. Hal ini didukung dengan teori Kozier (2004) yang mengatakan individu yang tidak memiliki kemampuan untuk mengidentifikasi masalah yang dimilikinya tersebut tentu dapat menghambat proses berkabung dan berkabung akan menjadi semakin lama.

Pada variabel ini sejalan dengan penelitian (Henny Frilasari dkk, 2012) dengan hasil uji pasti dari fisher (Fisher's Exact Test) dengan judul "Hubungan Dukungan Keluarga Dengan Respon Berduka Pada Klien Kanker Di Rumah Sakit Islam Sakinah Mojokerto". Dari hasil penelitiannya didapatkan dari 13 responden terdapat 9 responden yang mednpatkan dukungan keluarga yang baik. Hasil uji fisher (Fisher's Exact Test) didapatkan $\rho=0,008$, berarti $\rho<\alpha(0,05)$ sehingga $\mathrm{H}_{0}$ ditolak yang artinya ada hubungan antara dukungan keluarga dengan respon berduka pada klien kanker di Rumah Sakit Islam Sakinah Mojokerto.

\section{Hubungan Mekanisme Koping dengan Proses Berkabung}

Hasil penelitian menyimpulkan tidak ada hubungan mekanisme koping dengan proses berkabung pada pasien pre operasi kanker.

Menurut peneliti proses berkabung baik ada difase menerima (Acceptance) sedangkan untuk proses berkabung tidak baik ada di fase menyangkal (Denial), marah (Anger), tawar-menawar (Bargaining), dan depresi (Depression). Berduka atau berkabung adalah respon yang normal terhadap kehilangan (Potter \& Perry, 2005). Proses berduka merupakan proses yang normal dan perlu distimulasi dan di fasilitasi oleh lingkungan sosial agar segera sampai pada fase menerima (Keliat, 1998).

Respon berduka juga akan dipengaruhi oleh karakteristik pribadi, status sosio-ekonomi, hubungan yang alami, sistem pendukung sosial, mekanisme koping, kehilangan yang alami, tujuan, dan harapan (Suseno, 2005). Salah satu faktor yang dapat mempengaruhi respon berduka adalah mekanime koping dan dukungan sosial. Koping harus tersedia ketika klien yang berduka melalui proses berkabung (Potter \& Perry, 2005). Kurangnya penerapan mekanisme koping maladaptif biasanya menyebabkan kesulitan dalam keberhasilan resolusi berduka (Rando dalam Potter \& Perry, 2005).

Menurut Stuart dan Laraia (2005), mekanisme koping dipengaruhi oleh faktor ekternal dan faktor internal. Salah satu faktor ekternal adalah dukungan sosial terutama dukungan kelauarga. Menurut peneliti berhasil atau tidaknya mekanisme koping yang digunakan individu dapat mempengaruhi proses berkabung. Koping yaitu dimana seseorang beradapatasi dengan masalah yang dihadapi baik itu mengancam dirinya atau psikologis. 
Koping juga mampu memberikan pemahaman responden terhadap kehilangan yang dialami dirasakan yang mendalam dan mengancam keberhasilannya.

Penelitian Wurara dkk, (2013), yang menyatakan bahwa ada berbagai cara yang dilakukan pasien dalam mengahadapi masalah baik secara adaptif seperti bicara dengan orang lain, mampu menyelesaikan masalah, dan lain sebagainya.

Mekanisme koping yang dimunculkan pasien sebelum operasi kanker sangatlah dipengaruhi oleh dukungan sosial terutama dari keluarga yang mampu memberikan rasa aman dan nyaman sehingga koping seorang pasien menjadi efektif untuk melanjutkan ke fase menerima (Acceptance).

Hasil penelitian ini tidak sesuai dengan penelitian Supiah \& Rahayu (2012) mengenai hubungan koping dengan proses berduka pada pasien kanker payudara post mastektomi yang menyatakan bahwa adanya hubungan signifikan antara koping dengan proses berduka hasil tersebut menunjukkan bahwa pasien yang mandapatkan dukungan sosial yang baik akan memiliki mekanisme koping efektif dan mempercepat proses berkabung sampai ke fase menerima.

Menurut peneliti proses berkabung dipengaruhi banyak faktor, salah satunya dukungan sosial terutama keluarga, dukungan keluarga dapat memberikan koping yang adaptif untuk menyelesaikan proses berkabung. Oleh karena itu, responden yang tidak dapat adaptasi terhadap stress atau masalah dan tidak mendapatkan dukungan sosial yang baik akan berdampak pada proses berkabung dan berhenti disalah satu proses berkabung.

\section{KESIMPULAN}

Penelitian menyimpulkan bahwa ternyata tidak ada hubungan antara mekansime koping dengan proses berkabung pada pasien pre operasi kanker. Hal ini disebabkan karena proses berkabung dipengaruhi banyak faktor, salah satunya dukungan sosial terutama keluarga, dukungan keluarga dapat memberikan koping yang adaptif untuk menyelesaikan proses berkabung. Oleh karena itu, responden yang tidak dapat adaptasi terhadap stress atau masalah dan tidak mendapatkan dukungan sosial yang baik akan berdampak pada proses berkabung dan berhenti disalah satu proses berkabung.

Hasil penelitian merekomendasikan agar dilakukan penelitian selanjutnya untuk mencari faktor-faktor lain yang mampu mempercepat proses berkabung dan dapat digunakan sebagai salah satu sumber data untuk penelitian selanjutnya.

\section{DAFTAR PUSTAKA}

Dyanna, L., Dewi, Y. I., \& Herlina. (2015). Hubungan Dukungan Keluarga Terhadap Mekanisme Koping Pasien Post Operasi Mastektomi , 558-561. https://jom.unri.ac.id/index.php/JOM PSIK/article/view/8344,diakses tanggal 12 Februari 2018.

Kementerian Kesehatan Republik Indonesia. (2014). Buku Saku Pencegahan Kanker Leher Rahim dan Kanker Payudara. Jakarta: Kementerian Kesehatan Republik Indonesia.

Potter \& Perry. 2005. Buku Ajar Fundamental Keperawatan: Konsep, Proses \& Praktik, Ed.4, Vol.2. Jakarta: EGC

Wita. (2015). Respon Berduka Pada Pasien Stroke di RSUP Haji Adam Malik Medan3.repository.usu.ac.id/bitstrea m/handle/123456789/49678/Cover.p df? sequence $=7 . .$. , diakses tanggal 25 Februari 2018

World Health Organization. (2009). Cancer mortality and morbidity. 